\title{
Spontaneous Deposition of Ru on Pt (100): Morphological and Electrochemical Studies. Preliminary Results of Ethanol Oxidation at $\mathrm{Pt}(100) / \mathrm{Ru}$
}

\author{
Vinicius D. Colle, M. Janete Giz and Germano Tremiliosi-Filho*
}

\author{
Instituto de Química de São Carlos, Universidade de São Paulo, CP 780, 13560-970 São Carlos - SP, Brazil
}

\begin{abstract}
Neste trabalho rutênio foi depositado em níveis de sub-monocamadas sobre Pt (100) através da deposição espontânea em vários tempos de deposição. As superfícies de $\mathrm{Pt}(100) / \mathrm{Ru}$ foram analisadas pela técnica de STM ex-situ para visualizar a morfologia dos depósitos de rutênio formados sobre a superfície da Pt (100). Foi observada a formação de aglomerados de rutênio com diâmetros entre 1,0 e 4,5 nm e com espessura biatômica no centro das ilhas. Observou-se que as ilhas de rutênio estão homogeneamente distribuídas sobre os terraços da platina e não ocorre deposição preferencial sobre os degraus ou defeitos superficiais. O grau de recobrimento de rutênio foi avaliado pelo decréscimo das cargas voltamétricas dos picos de adsorção-dessorção de hidrogênio dos eletrodos $\mathrm{Pt}(100) / \mathrm{Ru}$. Os eletrodos $\mathrm{Pt}(100) / \mathrm{Ru}$ com grau de recobrimento de $\sim 0,3$ mostraram uma alta atividade para a eletrooxidação de etanol. Os resultados eletroquímicos suportam fortemente o mecanismo bifuncional para o aumento na oxidação do etanol.
\end{abstract}

In the present work ruthenium was deposited in submonolayer amounts on $\operatorname{Pt}(100)$ by spontaneous deposition at several deposition times. The Pt (100)/Ru surfaces were analyzed using ex-situ STM to image the deposits characteristic of ruthenium on Pt (100). It was observed the formation of ruthenium islands with diameters between 1.0 and $4.5 \mathrm{~nm}$ with bi-atomic thickness in the center of the islands. A homogeneous distribution of the ruthenium islands on the platinum terraces was found, with no preferential deposition on steps or surface defect sites. The ruthenium coverage degree had been calculated by the decrease of charge of the hydrogen adsorption-desorption peaks in the cyclic voltammograms of the $\mathrm{Pt}(100) / \mathrm{Ru}$ electrodes. The $\mathrm{Pt}(100) / \mathrm{Ru}$ electrodes with a ruthenium coverage degree of $c a$. 0.3 showed a high activity for the ethanol electrooxidation. The electrochemical experimental results support strongly the bifunctional mechanism for the enhanced ethanol oxidation.

Keywords: STM, cyclic voltammetry, $\mathrm{Pt}(100) / \mathrm{Ru}$, ethanol oxidation

\section{Introduction}

It is recognized that there are many ways to promote surface modifications in the level of submonolayers or monolayers of metal atoms on a substrate. A very well known way to realize an electrochemical surface modification of a metal substrate is through the called underpotential deposition phenomenon (UPD), where the metal atoms are deposited on a metal substrate that has a higher work function $(\phi) .{ }^{1}$ Once formed the film on a substrate, it can be arrayed in two-dimensional surface structure. Some aspects must be taken into account to determine a specific structure, like electrode material, electrode potential, surface crystallography, anion coadsorption and cationic precursor. Generally the films

* e-mail: germano@iqsc.sc.usp.br formed on the substrates are dissolved when a sufficiently positive electrode potential is reached.

The electrodeposition of sub-monolayers or monolayers is other way of getting metal deposits. In this case, the relationship between the work function of the substrate and that of the deposit is the opposite of that needed for UPD. ${ }^{1}$ Normally the films formed on the substrate do not dissolve easily and are very stable like oxides, instead, the films formed by UPD are reversible or quasi reversible. An important factor that must be considered to the formation of sub-monolayers and/or monolayers is the influence of the crystallographic orientation during the deposition process. Each specific face defines different arrays in function of the forces acting between adsorbateadsorbate and adsorbate-surface that are needed for the adlattice formation. $^{2}$

Recently, considerable attention has been devoted to 
the phenomenon of spontaneous deposition of "metals" on a substrate..$^{3-8}$ However, most of them are devoted to the surface modification of Pt (111) substrates, while just few ones are dedicated to studies of Pt (100) surface. ${ }^{3,6,8}$ One of the most studied modifiers of platinum surface is ruthenium, however other ad-metals, that can also be obtained by spontaneous deposition, have been used in electrocatalytic applications as $\mathrm{Rh},{ }^{9,10} \mathrm{Pd},{ }^{11} \mathrm{As},{ }^{12} \mathrm{Bi}^{13-15}$ and $\mathrm{Sb}^{12}$ as well.

It is well known that $\mathrm{Pt}$ is the best catalyst for the oxidation of small organic molecules, like methanol and ethanol. ${ }^{16}$ Its use can be promising as anode in fuel cell application. ${ }^{17}$ However, for this it is necessary to reach conditions where the rate, current densities, lifetime of the catalyst can be desirable. The main problem associated to organic eletrooxidation on platinum is the self-poisoning by $\mathrm{CO}$ molecule that is formed as a reaction intermediate and remains strongly adsorbed on the surface causing a decrease in the performance and reactivity of the catalyst. Promoters such as ruthenium have brought major improvement in the platinum tolerance to $\mathrm{CO}$ poisoning. . $^{3,4}$

Despite a lot of research on $\mathrm{Pt} / \mathrm{Ru}$ for methanol electrooxidation the nature of the surface site for the oxidation reaction is still an outstanding issue that needs to be addressed. In this context, the Scanning Tunneling Microscopy (STM) technique is a powerful tool that can reveal adequately information on the surface modification in sub-monolayer levels. In our case, the concern is in knowing the correlation between surface morphology of a catalyst and its performance towards organic oxidation.

In a recent publication Herrero et al. ${ }^{18}$ have studied the $\mathrm{Pt}(111) / \mathrm{Ru}$ system by ex situ STM and have showed the formation of $\mathrm{Ru}$ monatomic islands onto platinum surface. ${ }^{18}$ Additionally, they proposed that the surface structure of the deposit depends on the conditions used to realize the surface modification of $\operatorname{Pt}(111)$, by electrodeposition or spontaneous deposition. Also, Ru have been deposited on $\operatorname{Pt}(111)$ by metal evaporation under UHV conditions ${ }^{4,19}$ and the authors observed the presence of islands with sinuous border. As it was observed in the literature only the $\mathrm{Pt}(111) / \mathrm{Ru}$ surface was detailed studied.

Our goal is to analyze the $\mathrm{Pt}(100)$ surface modified by $\mathrm{Ru}$, using electrochemical and microscopy techniques to calculate the $\mathrm{Ru}$ coverage and to study the surface morphology of the obtained deposits. Finally, the catalytic ethanol eletrooxidation will be evaluated on the $\operatorname{Pt}(100) /$ Ru system.

\section{Experimental}

The Pt(100) single crystal was obtained by the Clavilier method described in the literature, ${ }^{20,21}$ where a bead of $c a$. $2 \mathrm{~mm}$ of diameter was grown and properly oriented by $\mathrm{X}$-ray technique. The single crystal was polished down to $0.05 \mu \mathrm{m}$ with alumina and submitted to a thermal treatment in hydrogen flame in order to regenerate the single crystal surface and eliminate impurities. Just after that, the crystal was cooled in hydrogen/argon atmosphere, to prevent surface disordering and was used as working electrode for the electrochemical experiments. ${ }^{22-24}$ For the STM measurement a commercial Pt(100) single crystal (Metal Crystals and Oxides Ltd) was used with ca. $5 \mathrm{~mm}$ in diameter and $7 \mathrm{~mm}$ in height and accuracy in the orientation of $0.4^{\circ}$. This single crystal electrode was also polished with alumina down to $0.05 \mu \mathrm{m}$.

The ruthenium deposition on platinum single crystal electrode was carried out by spontaneous deposition at the open circuit potential $\left(\mathrm{E}_{\mathrm{oc}}=910 \mathrm{mV}\right)$ from a ruthenium chloride/sulfuric acid $\left(1 \times 10^{-3} \mathrm{~mol} \mathrm{~L}^{-1} \mathrm{RuCl}_{3} \times \mathrm{xH}_{2} \mathrm{O}+0.1\right.$ mol L-1 $\left.\mathrm{H}_{2} \mathrm{SO}_{4}\right)$ solution. The ruthenium deposits were grown at several deposition times between 2 and 180 seconds. In order to avoid the formation of irreversible ruthenium oxides, after each deposition, the electrode was submitted to four voltammetric cycles in $0.1 \mathrm{~mol} \mathrm{~L}^{-1} \mathrm{H}_{2} \mathrm{SO}_{4}$ solution at the potential range of 0.05 to $0.5 \mathrm{~V}$ at $50 \mathrm{mV} \mathrm{s}^{-1}$.

All chemicals used for the preparation of the solutions were of high purity: $\mathrm{RuCl}_{3} \cdot \mathrm{xH}_{2} \mathrm{O}$ (Aldrich), $\mathrm{HClO}_{4}$ (Merck), $\mathrm{H}_{2} \mathrm{SO}_{4}$ (Mallinkrodt), ethanol (Mallinkrodt) and potassium iodide (Merck). All the solutions were prepared with Milli$\mathrm{Q}$ water (18.2 $\mathrm{M} \Omega \mathrm{cm})$.

The electrochemical experiments were carried out in a three compartments glass cell. All the electrolytic solutions were saturated with $\mathrm{N}_{2}$. The potentials were measured against a reversible hydrogen electrode (RHE). A platinum wire was used as counter electrode and the experiments were carried out at room temperature.

The ethanol electrooxidation reaction on $\mathrm{Pt}(100) / \mathrm{Ru}$ was preliminary studied by cyclic voltammetry and chronoamperometry in $0.5 \mathrm{~mol} \mathrm{~L}-1$ ethanol $+0.1 \mathrm{~mol} \mathrm{~L}^{-1}$ $\mathrm{H}_{2} \mathrm{SO}_{4}$ solution at a potential range of 0.05 to $0.8 \mathrm{~V}$ at 50 $\mathrm{mV} \mathrm{s}^{-1}$. The first voltammetric cycle for the ethanol oxidation was recorded for each deposition time. This procedure was followed due to the self-poisoning effect, which difficults the establishment of the influence of the deposits in the ethanol oxidation voltammetric profiles. The chronoamperometry technique was used to determine the current densities of ethanol oxidation as a function of time. Therefore, $1200 \mathrm{~s}$ was chosen as enough time to reach the almost steady state at $0.55 \mathrm{~V}$. This potential was chosen due to the influence of $\mathrm{Ru}$ to catalyze the oxidation of small organic molecules in overpotentials lower than that for Pt. At higher potentials ( $c a .0 .7 \mathrm{~V}$ ) platinum is active 
enough to favor the continuation of the reaction.

The study of the surface morphology of $\mathrm{Pt}(100) / \mathrm{Ru}$ system was carried out through the STM technique. The images were obtained by the ex situ method in argon atmosphere, using an instrument Pico SPM - Molecular Imaging Co., operating in the constant height mode. $\mathrm{Pt}_{0.8} \mathrm{Ir}_{0.2}$ tips prepared by electrochemical etching in concentrated $\mathrm{KOH}$ solution were used. The images were treated with the visual software SPM.

Before and after the ruthenium deposition, the electrode was cycled in $0.1 \mathrm{~mol} \mathrm{~L}^{-1} \mathrm{HClO}_{4}$ solution in the potential range of 0.06 to $0.8^{5,18,25}$ and just after that it was immersed in a $0.01 \mathrm{~mol} \mathrm{~L}^{-1} \mathrm{KI}+0.1 \mathrm{~mol} \mathrm{~L}^{-1} \mathrm{HClO}_{4}$ solution during 40 seconds. The perchloric acid was used because the perchlorate anion does not adsorb on platinum. The iodine adsorption on $\mathrm{Pt}(100)$ and $\mathrm{Pt}(100) / \mathrm{Ru}$ from potassium iodide solution, forms a protective $\mathrm{I}_{2}$ layer on the electrode. This procedure is necessary in order to prevent the surface disordering provoked by oxygen adsorption and to protect the surface from contamination, ${ }^{8,18,26}$ thus improving the quality of the STM images and allowing longer time to realize the STM experiments.

\section{Results and Discussion}

\section{Voltammetric profile of Pt (100)/Ru}

The obtained $\mathrm{Pt}(100)$ single crystal electrodes were first characterized by cyclic voltammetry in hangingmeniscus pattern, in $0.1 \mathrm{~mol} \mathrm{~L}^{-1} \mathrm{H}_{2} \mathrm{SO}_{4}$ saturated with $\mathrm{N}_{2}$ at the potential range of 0.05 to $0.8 \mathrm{~V}$ at $50 \mathrm{mV} \mathrm{s}^{-1}$. Before each measurement, the electrode of $c a .2 .2 \mathrm{~mm}$ in diameter, was always flame-annealed in hydrogen flame for $5 \mathrm{~min}$ and cooled in hydrogen/argon (1:1) atmosphere. To avoid atmospheric contamination a drop of water was used to protect the electrode surface during the transfer to the electrochemical cell. Once the voltammetric profiles of $\operatorname{Pt}(100)$ were in accordance with literature, ${ }^{27-30}$ it was possible to start the spontaneous $\mathrm{Ru}$ deposition.

Figure 1 shows the cyclic voltammograms for $\mathrm{Pt}(100) /$ $\mathrm{Ru}$ electrodes obtained in $0.1 \mathrm{~mol} \mathrm{~L}^{-1} \mathrm{H}_{2} \mathrm{SO}_{4}$ at the potential range of 0.05 to $0.5 \mathrm{~V}$ at $50 \mathrm{mV} \mathrm{s}^{-1}$ for $\mathrm{Ru}$ spontaneous deposition time of 10, 60 and $180 \mathrm{~s}$. This potential range was chosen in order to avoid the formation of irreversible ruthenium oxides. In all cases just the $4^{\text {th }}$ cycle was recorded. For comparison, the voltammogram for clean Pt (100) is presented in the potential range of 0.05 and $0.8 \mathrm{~V}$. It can be observed that for all deposition times there is a gradual decrease in the peak centered around of $0.4 \mathrm{~V}$, which corresponds to both the hydrogen and the anion adsorption/desorption peaks for the Pt (100). Also, an increase of the current density at the range of 0.05 to $0.3 \mathrm{~V}$ it is clearly seen, when compared to that of clean Pt (100). This behavior has been attributed to two effects: the weak hydrogen adsorption on the deposited ruthenium (surface modifier), as previously proposed in the literature for metallic ruthenium, ${ }^{31}$ and an increase of the specific surface area due to the presence of $\mathrm{Ru}$ particles on the Pt (100) surface.

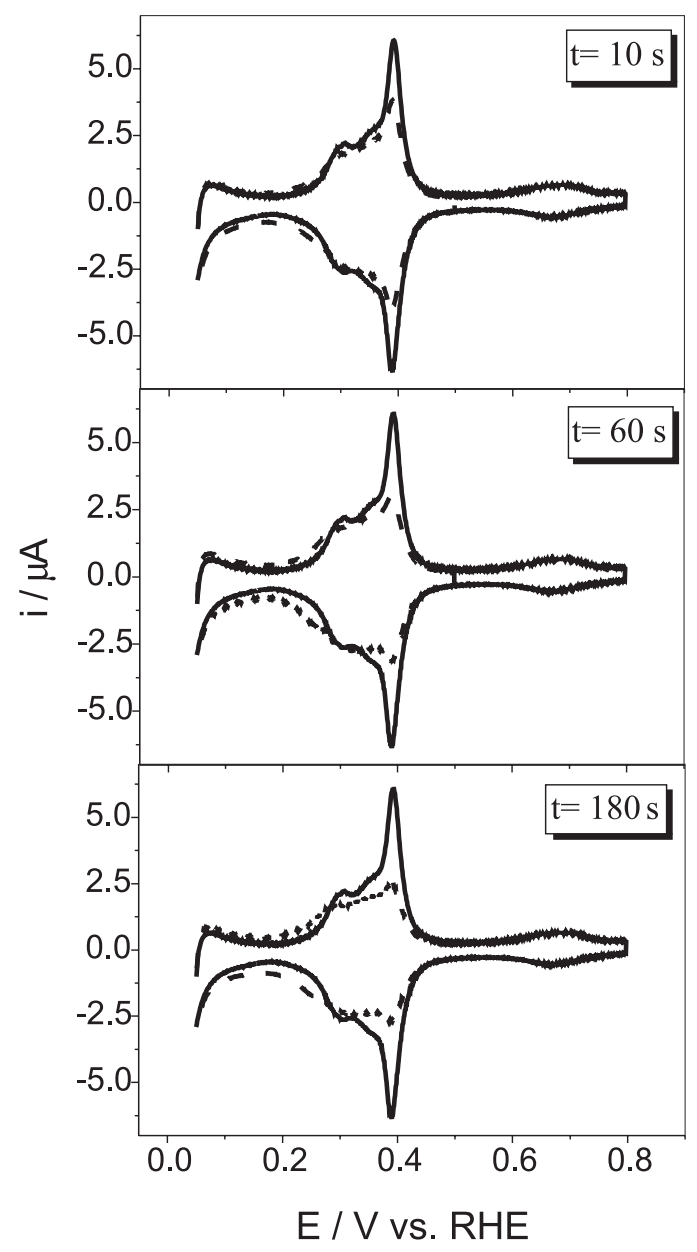

Figure 1. Cyclic voltammograms obtained in $0.1 \mathrm{~mol} \mathrm{~L}^{-1} \mathrm{H}_{2} \mathrm{SO}_{4}$ at $50 \mathrm{mV} \mathrm{s}^{-1}$ for: (---) clean $\mathrm{Pt}(100)$ electrode and (-) $\mathrm{Pt}(100) / \mathrm{Ru}$ electrodes obtained at different spontaneous ruthenium deposition times from $\mathrm{RuCl}_{3} / \mathrm{H}_{2} \mathrm{SO}_{4}$ solution.

By comparimg the hydrogen adsorption charge for the $\mathrm{Pt}(100) / \mathrm{Ru}$ electrode with that for clean Pt (100) the hydrogen coverage for each deposition time can be determined according to the following equation:

$\theta_{H}=\frac{\boldsymbol{Q}_{H}{ }^{P t R u}}{\boldsymbol{Q}_{H}{ }^{P t}}$

where $\mathrm{Q}_{\mathrm{H}}{ }^{\mathrm{Pt} / \mathrm{Ru}}$ and $\mathrm{Q}_{\mathrm{H}}{ }^{\mathrm{Pt}}$ are the hydrogen/anion desorption charges (in the potential range of 0.15 and $0.50 \mathrm{~V}$ ) after 
and before ruthenium deposition, respectively. The decrease of the hydrogen/anion adsorption peaks as a function of the increase of the deposition time suggests that hydrogen atoms are not strongly adsorbed on the ruthenium deposits. So, it is possible to estimate the ruthenium coverage by using the values of hydrogen/anion coverage through the equation:

$\theta_{R u}=1-\theta_{H}$

This equation was used under the assumption that charges for the hydrogen and the anion adsorption/ desorption contribute in the same extension to the variation of the ruthenium coverage.

The values of ruthenium coverage degree on $\operatorname{Pt}(100)$ calculated from the equations above for deposits grown up to $180 \mathrm{~s}$ are shown in Figure 2. The tendency of saturation in the ruthenium coverage is clearly observed. A maximum value for the coverage degree of 0.35 monolayer is obtained for the deposition time of $180 \mathrm{~s}$. This behavior is in accordance with the literature ${ }^{3}$ and supports the assumption stated above regarding the same contribution of the hydrogen and of the anion adsorption to the changes in the experimental charges associated with the ruthenium coverage. Tremiliosi-Filho and co-workers, ${ }^{7}$ studying the spontaneous deposition of ruthenium on $\operatorname{Pt}(111)$ have concluded that the coverage degree does not reach higher values because of a significant presence of ruthenium oxides in the deposit composition, which difficult the deposition process with the consequent limitation of the growth of the deposit.

Additionally, they have analyzed the chemical composition of the spontaneously deposited ruthenium

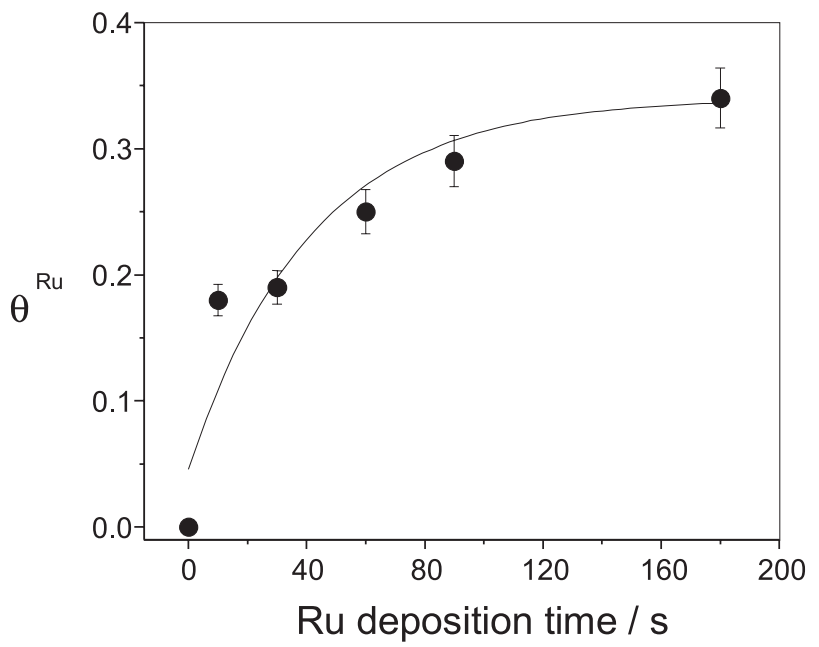

Figure 2. Coverage degree of $\mathrm{Ru}$ species deposited on $\mathrm{Pt}(100)$ by spontaneous deposition and calculated from voltammetric hydrogen adsorption peaks . on $\mathrm{Pt}(111)$ by $\mathrm{XPS}^{7}$ and they proposed that a large amount of surface oxygen is present as ruthenium oxides or hydroxides. However, these spontaneously formed ruthenium oxo-species decompose mainly to metallic ruthenium under voltammetric conditions. There is no information in the literature concerning the chemical composition of the system $\mathrm{Pt}(100) / \mathrm{Ru}$ but it is believed that it follows the same as observed for $\mathrm{Pt}(111) / \mathrm{Ru}$.

\section{STM studies of $\mathrm{Pt}(100) / \mathrm{Ru}$}

Figure 3 shows the STM image obtained for a clean $\mathrm{Pt}(100)$ electrode following the procedure described at the experimental section. The presence of terraces delimited by random monoatomic steps is observed (Figure3A). In other small regions of this same surface (Figure $3 \mathrm{~B}$ ) the

(A)

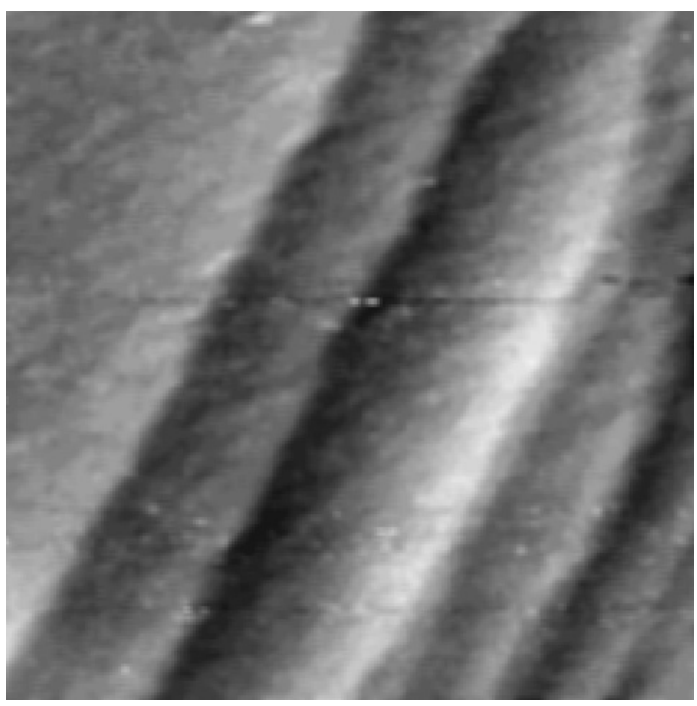

(B)

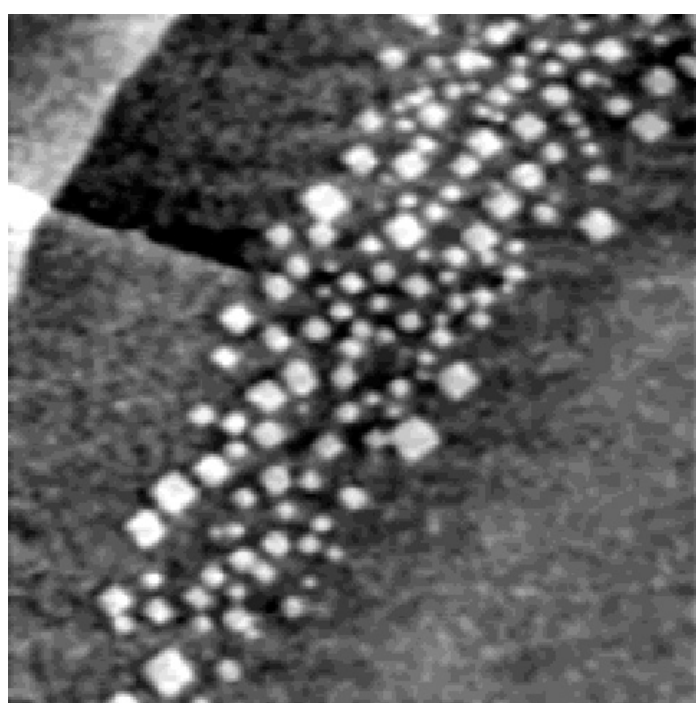

Figure 3. Ex situ STM images obtained for clean $\operatorname{Pt}(100)$ surface: (A) Resolution of $200 \times 200 \mathrm{~nm}$, (B) resolution $500 \times 500 \mathrm{~nm}$ (different surface region). 
formation of high monoatomic, square-shaped islands is also observed. The presence of such islands on the surface is a clear indication that the surface was partially disordered. Kolb and co-workers reported similar observation when using high $\mathrm{H}_{2}$ concentration in the cooling atmosphere. ${ }^{24}$ The STM images in the presence of ruthenium deposits were obtained in the region where the square-shaped islands were not present.

The STM images obtained for the $\mathrm{Pt}(100) / \mathrm{Ru}$ surface prepared by different deposition times are presented in Figures 4 and 5.

Figure 4A presents the STM image of $\mathrm{Pt}(100)$ after ruthenium deposition during $3 \mathrm{~s}$. It is only seen the platinum terraces delimited by monoatomic steps and no formation of the ruthenium deposits on the $\mathrm{Pt}$ (100) surface is observed in the used resolution of 100x100 nm. Under this deposition time the degree of coverage is lower than 0.1 monolayer. A reasonable explanation for the not observing surface ruthenium deposits on $\operatorname{Pt}(100)$ after $3 \mathrm{~s}$ of spontaneous deposition is associated with the STM sensitivity that is not enough to detect traces of small spots (nucleus) of ruthenium on the platinum crystal. However, after $20 \mathrm{~s}$ of ruthenium deposition (Figure 4B) the definition of small spots on $\mathrm{Pt}(100)$ is clear. The observable bright spots are ruthenium islands homogeneously spread on the platinum surface, with no preferential deposition on the steps or edges. The average values of the islands diameter and area are $c a .2 .04 \mathrm{~nm}$ and $3.26 \mathrm{~nm}^{2}$, respectively.

In the case of deposition time of $60 \mathrm{~s}$, the images were acquired under two conditions: before (Figure 5A) and after (Figure 5B) conditioning the electrode by four voltammetric cycles in $\mathrm{HClO}_{4}$ solution just after the deposition process, in order to check the effect of the voltammetric treatment on the surface morphology.

Similar observation can be done for platinum surface modified by ruthenium deposition during $60 \mathrm{~s}$ (see Figure $5 \mathrm{~A})$. In this case, the statistical analysis of the islands dimensions reveals an average value of $2.53 \pm 0.85 \mathrm{~nm}$ and $0.51 \pm 0.13 \mathrm{~nm}$ for diameter and height, respectively. The height of the islands corresponds to the formation of a ruthenium bilayer, although a full monoatomic layer has not been detected. These values are in good agreement with the literature. ${ }^{5,8}$

When the $\mathrm{Pt}(100) / \mathrm{Ru}$ surface is submitted to the voltammetric treatment between 0.06 and $0.8 \mathrm{~V}$ (four cycles) in $0.1 \mathrm{~mol} \mathrm{~L}^{-1} \mathrm{HClO}_{4}$ solution, no significant change is observed on the distribution and size of $\mathrm{Ru}$ islands, as can be seen in Figure 5B. The average value for the islands diameter is $2.27 \pm 0.52 \mathrm{~nm}$ and their height is $c a .0 .40 \pm$ $0.07 \mathrm{~nm}$. According to Wieckowski and co-workers, ${ }^{8}$ the voltammetric treatment in $\mathrm{HClO}_{4}$ solution in the potential
(A)

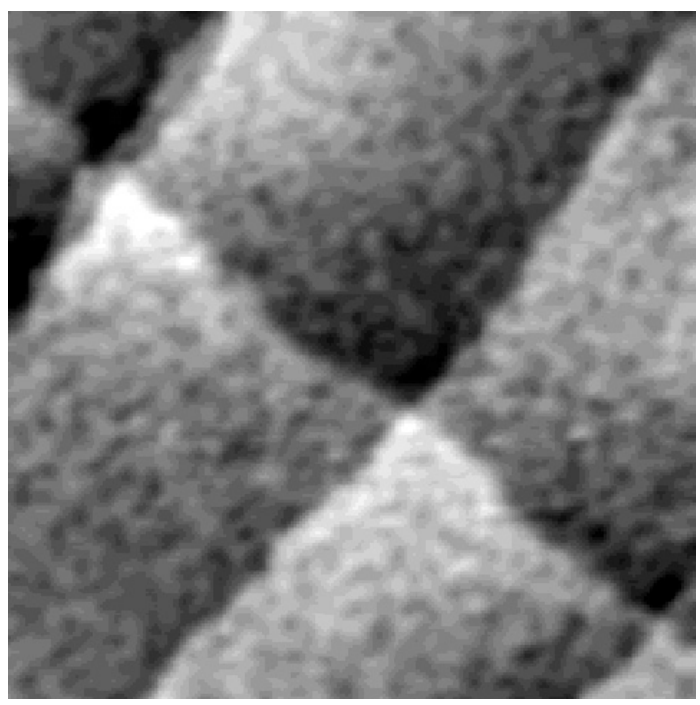

(B)

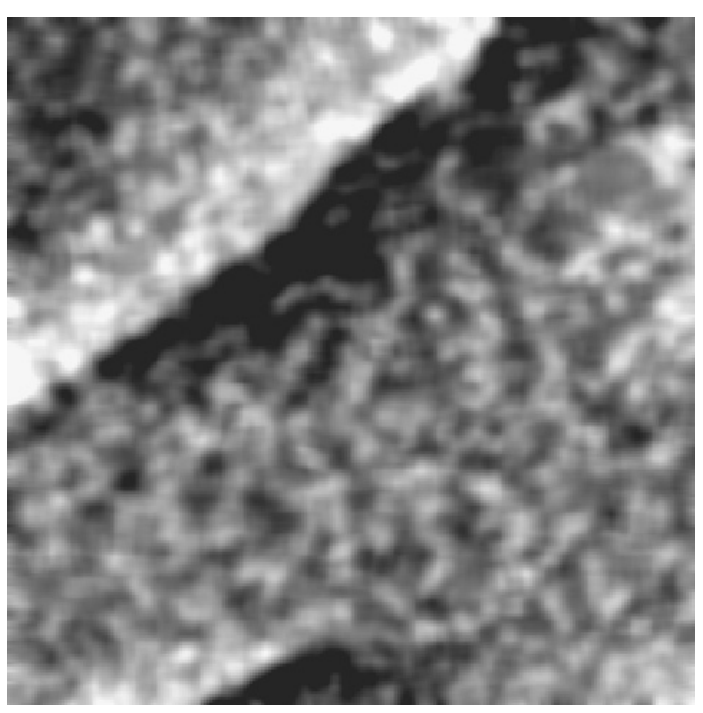

Figure 4. Ex situ STM images obtained for $\operatorname{Pt}(100) / \mathrm{Ru}$ : (A) after $3 \mathrm{~s}$ of ruthenium deposition $(100 \times 100 \mathrm{~nm})$ and (B) after $20 \mathrm{~s}$ of ruthenium deposition $(70 \times 70 \mathrm{~nm})$.

range of 0.06 to $0.8 \mathrm{~V}$ reduces the $\mathrm{RuO}^{2+}$ species and forms strongly adsorbed elemental ruthenium and others ruthenium oxides species. This supports the observable reduction of the island height after the voltammetric cycling.

A more careful statistical analysis of the islands dimensions is shown in the histogram of Figures 6 and 7 , for $\mathrm{Pt}(100)$ modified by ruthenium deposition during $60 \mathrm{~s}$ before and after voltammetric treatment.

The histograms shown in Figure 6A and 6B present the area and diameter size distributions of the islands before voltammetric treatment. Most of the islands have an area of $c a .2 .5 \mathrm{~nm}^{2}$, varying in the range of 0.3 and $10 \mathrm{~nm}^{2}$. For the diameter, the largest amount of particles is concentrated around $2.0 \mathrm{~nm}$ varying from 1.0 to $4.5 \mathrm{~nm}$. After the 
(A)

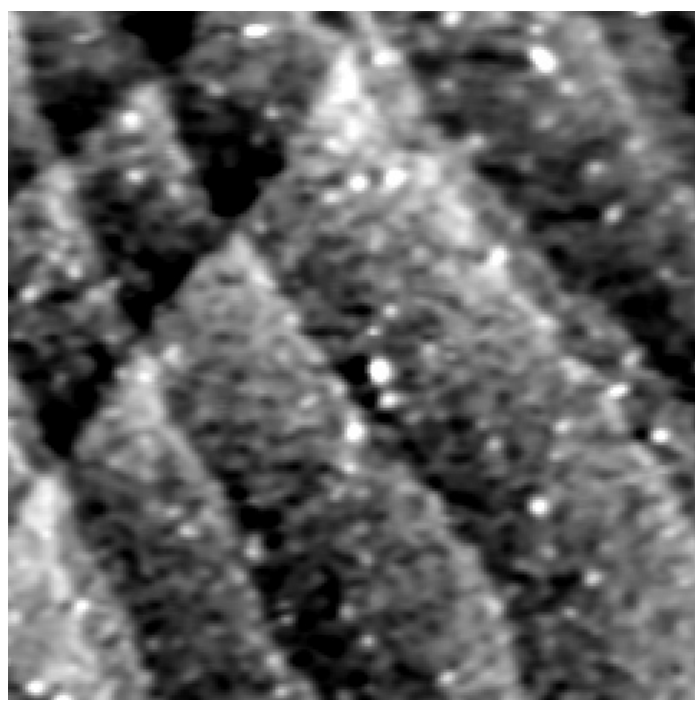

(B)

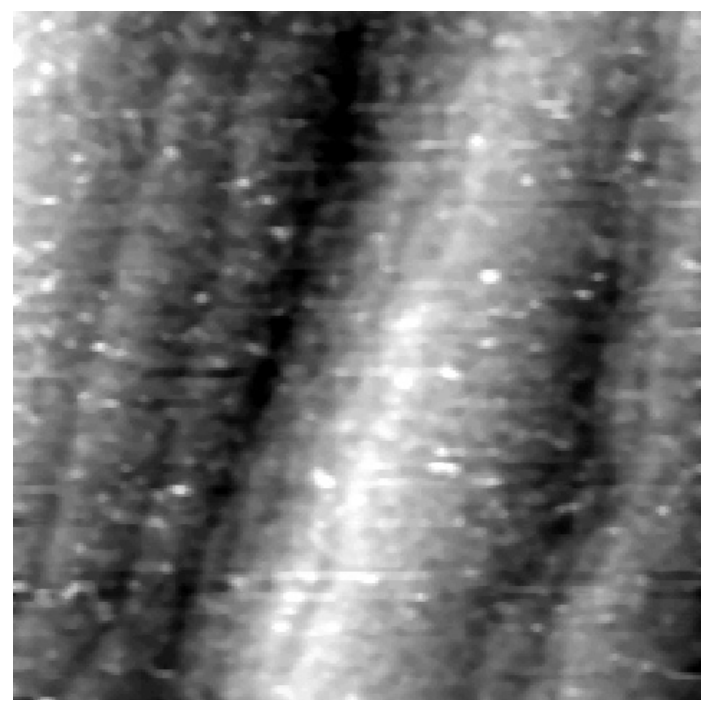

Figure 5. Ex situ STM images obtained for Pt(100)/Ru: (A) after $60 \mathrm{~s}$ of ruthenium deposition without voltammetric treatment $(100 \mathrm{x}$ $100 \mathrm{~nm}$ ) and (B) after $60 \mathrm{~s}$ of ruthenium deposition and after voltammetric treatment in $\mathrm{HClO}_{4}(100 \times 100 \mathrm{~nm})$.

voltammetric treatment the majority of the islands have an area of $2.8 \mathrm{~nm}^{2}$ that is a little larger than that in the previous case, indicating that a partial particle agglomeration is facilitated by the electrochemical treatment. The diameter remains approximately equal (2.0 $\mathrm{nm}$ ) varying between 1.0 and $3.5 \mathrm{~nm}$. Additionally, it can be seen from the histograms that after the electrochemical treatment the total amount of islands decreases after the voltammetric cycling indicating a partial dissolution of the surface deposited ruthenium.

\section{Ethanol electrooxidation on $\operatorname{Pt}(100) / R u$}

Ethanol electrooxidation was studied in $0.1 \mathrm{~mol} \mathrm{~L}^{-1}$ ethanol $+0.1 \mathrm{~mol} \mathrm{~L}^{-1} \mathrm{H}_{2} \mathrm{SO}_{4}$ solution, in order to correlate the catalytic activity of the $\mathrm{Pt}(100) / \mathrm{Ru}$ system with the ruthenium coverage degrees.

Figure 8 shows the voltammetric profile for a clean $\mathrm{Pt}$ (100) surface. The anodic peak for ethanol oxidation on $\mathrm{Pt}$ (100) occurs around $0.780 \mathrm{~V}$. The voltammogram presents hysteresis between the anodic and the cathodic sweeps, in which a higher ethanol oxidation charge is observed in the cathodic sweep together a shift of the peak to lower potentials. This feature is due to the fact that the ethanol adsorption in the anodic sweep competes with the strong adsorption of water, $\mathrm{CO}$ or other carbonaceous species, formed as intermediates, during the course of the reaction. All of these species are oxidized to $\mathrm{CO}_{2}$ in potentials as high as $780 \mathrm{mV}$, liberating the active reaction sites and increasing the efficiency of the ethanol oxidation in the cathodic sweep. ${ }^{32}$

The studies of the catalytic activity of the platinum surface modified by ruthenium deposition were carried out using only the anodic sweep of the voltammograms. The corresponding anodic voltammetric sweeps for three
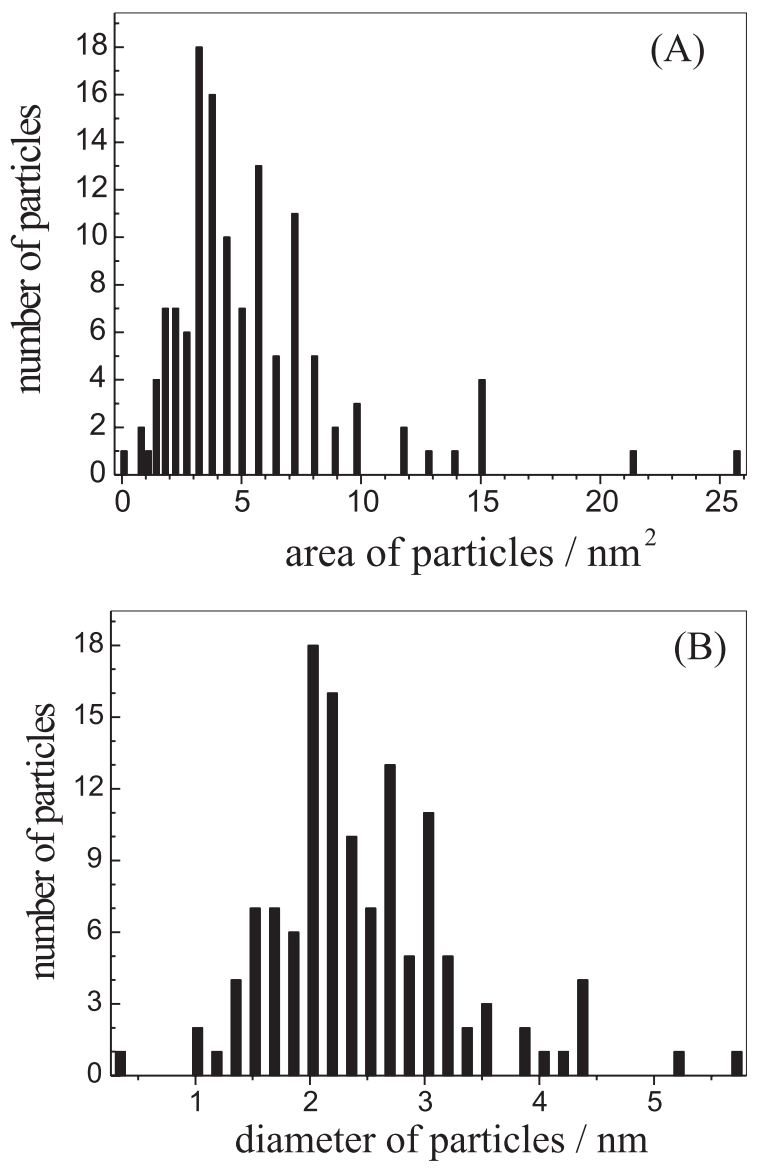

Figure 6. Statistical histograms: (A) Number of particles vs distribution of areas of ruthenium particles deposited during $60 \mathrm{~s}$ (without voltammetric treatment). (B) Number of particles $v s$ distribution of diameters of ruthenium particles deposited during $60 \mathrm{~s}$ (without voltammetric treatment). 
different deposition times are shown in Figure 9. A significant anodic current (shoulder) is observed for ethanol oxidation on $\mathrm{Pt}(100) / \mathrm{Ru}$ at lower potentials compared with
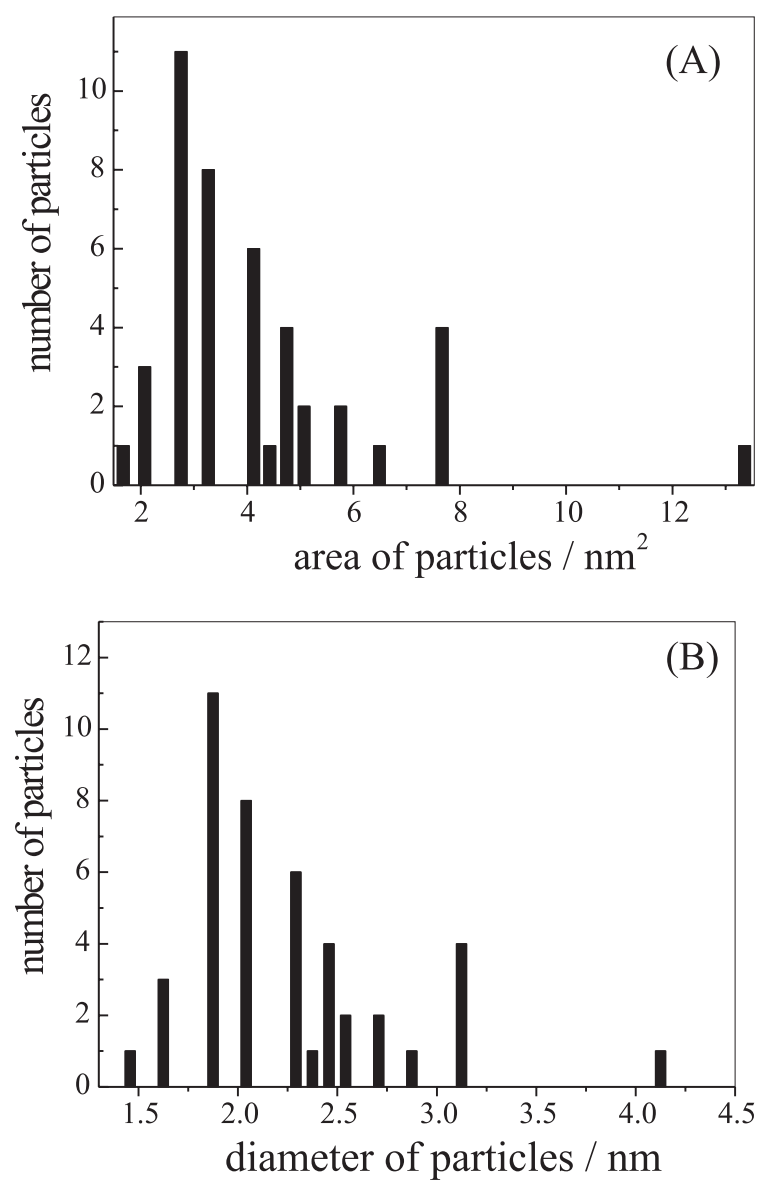

Figure 7. Statistical histograms: (A) Number of particles $v s$ distribution of areas of ruthenium particles deposited during $60 \mathrm{~s}$ (with voltammetric treatment). (B) Number of particles $v s$ distribution of diameters of ruthenium particles deposited during $60 \mathrm{~s}$ (with voltammetric treatment).

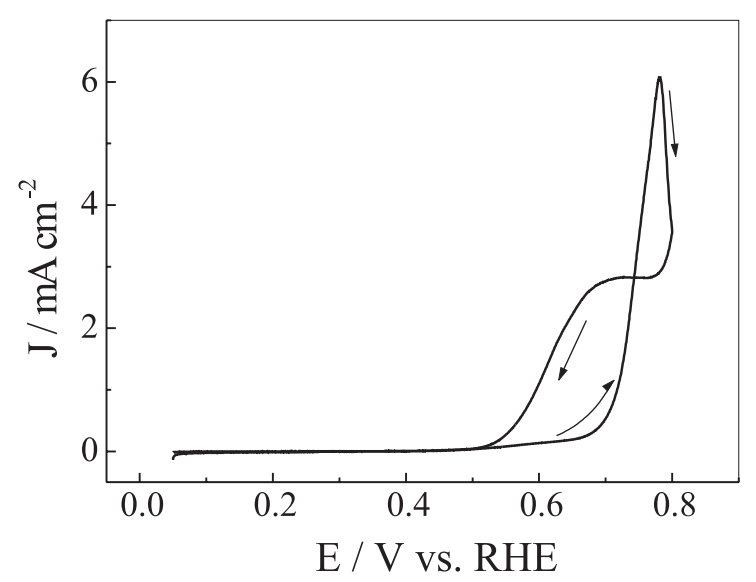

Figure 8. Cyclic voltammogram for the ethanol oxidation on clean $\mathrm{Pt}(100)$ in $0.1 \mathrm{~mol} \mathrm{~L}^{-1}$ ethanol $+0.1 \mathrm{~mol} \mathrm{~L}^{-1} \mathrm{H}_{2} \mathrm{SO}_{4}$ solution. $\mathrm{v}=20$ $\mathrm{mV} \mathrm{s}^{-1}$. that for the non-modified electrode. This indicates a higher activity of the modified surface and a larger tolerance to the poisoning by adsorbed species formed in potentials lower than $780 \mathrm{mV}$. At low overpotentials (between 50 and 600 $\mathrm{mV}$ ), which is showed in details in Figure 9 as an inset, it is also observed that the highest densities of ethanol oxidation occur after different Ru deposition times.

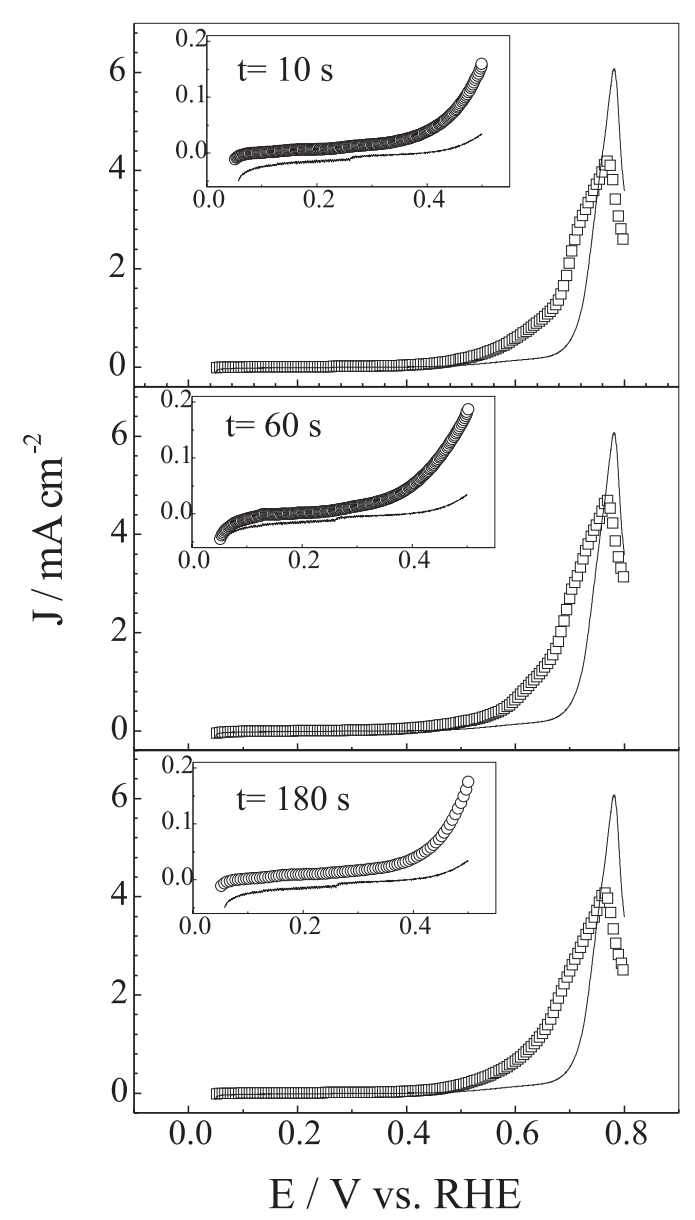

Figure 9. Anodic voltammetric sweeps for ethanol oxidation on clean $\mathrm{Pt}(100)$ (-) and $\mathrm{Pt}(100) / \mathrm{Ru}\left(-\mathrm{O}_{-}\right)$electrodes in $0.1 \mathrm{~mol} \mathrm{~L}^{-1}$ ethanol $+0.1 \mathrm{~mol} \mathrm{~L}^{-1} \mathrm{H}_{2} \mathrm{SO}_{4}$ solution. $\mathrm{v}=20 \mathrm{mV} \mathrm{s}^{-1}$, for different $\mathrm{Ru}$ deposition times.

The chronoamperometric curves obtained for Pt (100) and $\mathrm{Pt}$ (100)/Ru electrodes, presented in Figure 10, confirm the best performance of the modified electrode for the ethanol oxidation. A plot of the final chronoamperometric current (measured after $20 \mathrm{~min}$ of polarization at $0.550 \mathrm{~V}$ ) as a function of the ruthenium deposition time is shown in Figure 11.

The shape of the resulting curve infers that the deposition time of $90 \mathrm{~s}$ of spontaneous deposition of ruthenium exhibits the best catalytic activity. At higher deposition times, the current decreases. This information 
is in agreement with the bifunctional mechanism for the ethanol oxidation on modified electrodes, proposed in the literature. ${ }^{33,34}$ The maximum reactivity achieved for a deposition time of $90 \mathrm{~s}$ can be associated with the chemical state of ruthenium. The distribution of ruthenium valencies in deposits obtained by spontaneous deposition contains $\mathrm{Ru}^{4+}$ (as $\mathrm{RuO}_{2}$ ), $\mathrm{Ru}^{6+}$ (as $\mathrm{RuO}_{3}$ ) and $\mathrm{Ru}^{0}$ (metallic phase), and the catalytic enhancement is associated with the presence of metallic ruthenium. ${ }^{7}$ Coincidentally, the Pt/ $\mathrm{Ru}$ surface obtained by spontaneous deposition for $90 \mathrm{~s}$ promotes the appearance of more metallic species than the other studied deposition times (this assumption should be verified by XPS measurements). An important prerequisite for higher ethanol oxidation activity is to achieve a catalyst surface of highly metallic character. In this way, the bifunctional mechanism operates for the enhancement of ethanol electrooxidation. When metallic ruthenium is present in the surface, the ethanolic $\mathrm{C}-\mathrm{C}$ bond breaks on the Pt surface site forming adsorbed $\mathrm{CO}$. Water is activated on the surface of metallic ruthenium, and acts as the source

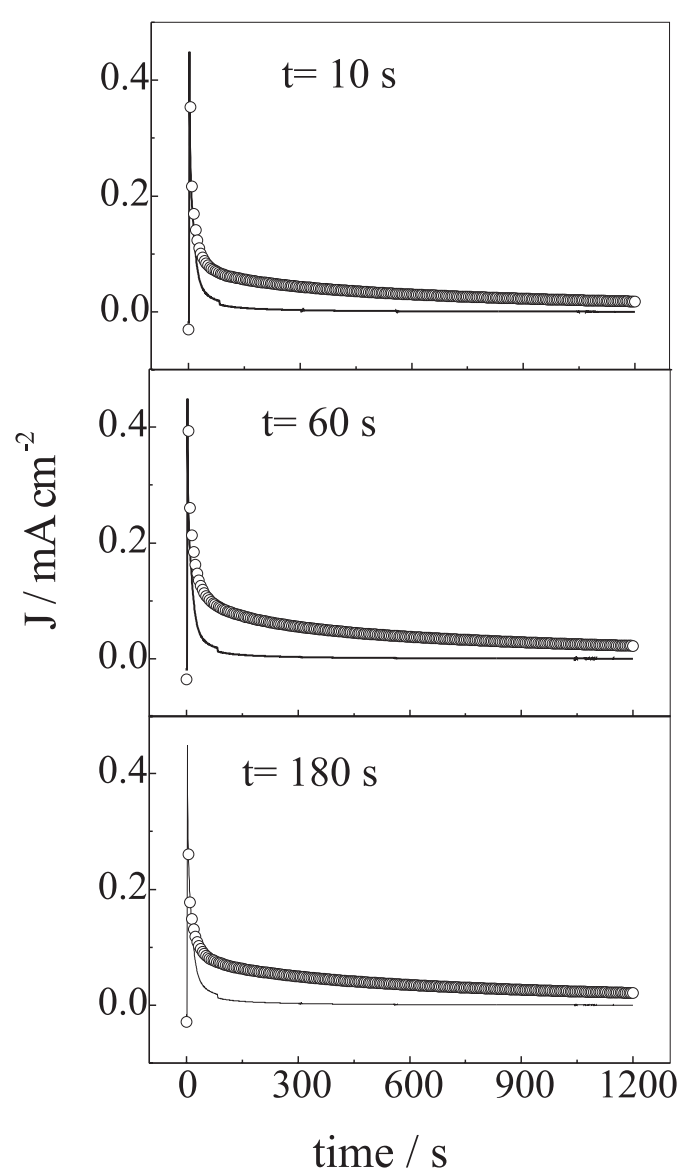

Figure 10. Chronoamperometric curves for ethanol oxidation at $0.55 \mathrm{~V}$ on clean $\mathrm{Pt}(100)(-)$ and $\mathrm{Pt}(100) / \mathrm{Ru}\left(-\mathrm{O}_{-}\right)$electrodes in $0.1 \mathrm{~mol} \mathrm{~L}^{-1}$ ethanol $+0.1 \mathrm{~mol} \mathrm{~L}^{-1} \mathrm{H}_{2} \mathrm{SO}_{4}$ solution, for different $\mathrm{Ru}$ deposition times.

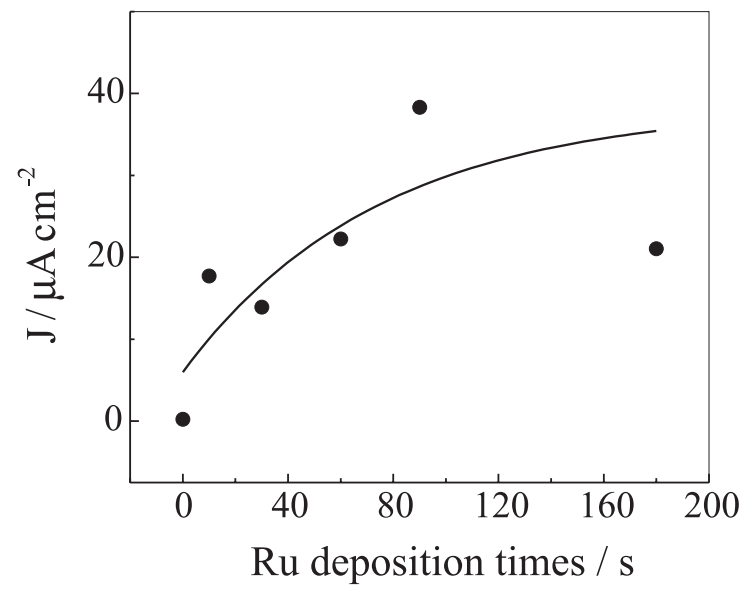

Figure 11. Current densities of ethanol oxidation after 1,200 seconds at $0.55 \mathrm{~V}$, as a function of the $\mathrm{Ru}$ deposition time.

of oxygen needed for the catalytic transformation of surface $\mathrm{CO}$ to $\mathrm{CO}_{2}$ at the edge of ruthenium islands. ${ }^{7,18}$

\section{Conclusions}

STM images of Pt (100)/Ru showed the formation of ruthenium islands, uniformly distributed on the electrode surface. These islands have diameters between 1 and 4.5 $\mathrm{nm}$ and have a bi-atomic thickness in the center of the islands.

The ruthenium coverage degrees on $\mathrm{Pt}$ (100)/Ru did not show significant change in their values with the increase of the deposition time, exhibiting an average value of 0.3 .

Experimental results have shown that $\mathrm{Pt}(100) / \mathrm{Ru}$ electrodes present higher current densities at low potentials for ethanol oxidation than non-modified Pt (100). This fact supports that the Pt (100) modified by ruthenium produces intermediated reaction and probably final products at lowest overpotential, where the $\mathrm{Pt}(100)$ is not enough to cause it through the by bifunctional mechanism.

\section{Acknowledgements}

V. Del Colle acknowledges FAPESP for a scholarship granted (99/12099-2). The authors also thank FAPESP, CNPq and CAPES (Brazil) for financial support.

\section{References}

1. Kolb, D. M.; Przasnycki, M.; Gerisher, H. J.; J. Electroanal. Chem. 1974, 54, 25.

2. Sung, Y. -E.; Chrzanowski, W.; Zolfaghari, A.; Jerkiewicz, G.; Wieckowski, A.; J. Am. Chem. Soc. 1997, 119, 194. 
3. Tremiliosi-Filho, G.; Kim, W.; Chrzanowski, W.; Wieckowski, A., B. Grzybowska, P. Kulesza; J. Electroanal. Chem. 1999, 467, 143.

4. Iwasita, T.; Hoster; H.; John-Anacker; A.; Lin, W. F.; Vielstich, W.; Langmuir 2000, 16, 522.

5. Crown, A.; Moraes, I. R.; Wieckowski, A.; J. Electroanal. Chem. 2001, 500, 333.

6. Chrzanowski, W.; Wieckowski, A.; Langmuir 1997, 13, 5974

7. Kim, H.; Moraes, I.; R.; Tremiliosi-Filho, G.; Haasch, R.; Wieckowski, A.; Surf. Sci. 2001, 474, L203.

8. Crown, A.; Johnston, C.; Wieckowski, A.; Surf. Sci. 2002, 506, L268.

9. Bakos, I.; Szabo, S.; J. Electroanal. Chem. 2003, 547, 103.

10. Gomez, R.; Feliu, J. M.; Electrochim. Acta 1998, 44, 1191.

11. Carbo, R.; Albalat, R.; Claret, J.; Electrochim. Acta 1998, 44, 1097.

12. Feliu, J. M.; Fernandez-Vega, A.; Aldaz, A.; Clavilier, J.; J. Electroanal. Chem. 1998, 256, 149.

13. Clavilier, J. Feliu, J. M.; Aldaz, A.; J. Electroanal. Chem. 1998 , $243,419$.

14. Evans, R. W.; Attard, G. A.; J. Electroanal. Chem. 1993, 345, 337.

15. Feliu, J. M.; Fernandez-Vega, A.; Aldaz, A.; Clavilier, J.; $J$. Electroanal. Chem. 1998, 269, 175.

16. Vielstich, W.; Fuel Cells: Modern Processes for the Electrochemical Production of Energy, Wiley: New York, 1970.

17. Wang, J.; Wasmus, S.; Savinell, R. F.; J. Electroanal. Chem. 1995, 142, 4218.

18. Herrero, E.; Feliu, J. M.; Wieckowski, A.; Langmuir 1999, 15, 4944.

19. Jarvi, T. D.; Madden, T. H.; Stuve, E. M.; Electrochem. SolidState Lett. 1999, 2, 224.
20. Clavilier, J.; Armand, D.; Sun, S. G.; Petit, M.; J. Electroanal. Chem. 1986, 205, 267.

21. Dall'Antonia, L. H.; Perez, J.; Tremiliosi-Filho, G.; Gonzalez, E. R.; Quim. Nova 1999, 22, 760.

22. Feliu, J. M.; Rodes, A.; Orts, J. M.; Clavilier, J.; Pol. J. Chem. 1999, 68, 1575.

23. Kolb, D. M.; Prog, Surf. Sci. 1996, 51, 109.

24. Kibler, L. A.; Cuesta, A.; Kleinert, M.; Kolb, D. M.; J. Electroanal. Chem. 2000, 484, 73.

25. Frelink, T.; Visscher, W.; Van Veen, J.A.R.; Langmuir 1996, 12, 3702 .

26. Orts, J. M.; Gómez, R.; Feliu, J. M.; Aldaz, A.; Clavilier, J.; Langmuir 1997, 13, 3016.

27. Clavilier, J.; Armand, D.; Wu, B. L.; J. Electroanal. Chem. 1982, 135, 159

28. Clavilier, J.; Armand, D.; J. Electroanal. Chem. 1986, 199, 187.

29. Clavilier, J.; Armand, D.; Sun, S. G.; Petit, M.; J. Electroanal. Chem. 1986, 205, 267.

30. Rodes, A.; Clavilier, J.; J. Electroanal. Chem. 1992, 338, 317.

31. Woods, R. In Electroanalytical Chemistry; Bard, A. J.; ed.; Marcel Dekker: New York, 1976, vol. 9.

32. Xia, X. H.; Liess, H. D.; Iwasita, T.; J. Electroanal.Chem. 1997, 437, 233.

33. Watanabe, M.; Motoo, S.; J. Electroanal. Chem. 1975, 60, 275.

34. Watanabe, M.; Motoo, S.; J. Electroanal. Chem. 1975, 60, 267.

Received: February 3, 2003

Published on the web: August 15, 2003

FAPESP helped in meeting the publication costs of this article. 